\title{
다발성 뇌해면기형
}

\author{
정성훈 유봉구 \\ 고신대학교 복음병원 신경과
}

\section{Multiple Cerebral Cavernous Malformations}

\author{
Seonghun Jeong, MD, Bong-Goo Yoo, MD \\ Department of Neurology, Kosin University Gospel Hospital, Busan, Korea
}

J Korean Neurol Assoc 37(3):310-311, 2019

59세 여자가 어지러움, 두통과 안면통으로 병원에 왔다. 뇌 자기 공명영상에서 $\mathrm{T} 1$ 강조영상, $\mathrm{T} 2$ 강조영상, 액체감쇠역전회복영상, 조 영증강 T1강조영상에서 이상이 없었고(Fig. A-D), 감수성강조영상 에서 다양한 크기의 다발성 저신호강도가 광범위하게 보였다(Fig. E-H). 자기공명영상으로 다발성 뇌해면기형으로 진단하였다. 가족 성뇌해면기형의 진단기준은 5 개 이상의 병변, 가족 중에 2 명 이상 에서 발현, 관련 유전자의 돌연변이 중에 한 가지만 만족하여도 진 단할 수 있다. ${ }^{1}$ 가족성뇌해면기형은 자기공명영상을 기준으로 4 가 지 형으로 분류한다. ${ }^{2}$ 제 4 형은 점 모양의 저신호 병변이 감수성강 조와 기울기에코영상에서 관찰되나, T1과 $\mathrm{T} 2$ 강조영상에서는 병변 이 보이지 않는다. ${ }^{2}$ 미세출혈의 크기가 다양하고, 고혈압이나 뇌아 밀로이드혈관병증으로 인한 미세출혈 호발 부위 외의 병변이 있는
것은 뇌해면기형과 관련될 가능성이 높다. 본 증례는 다양한 크기 의 많은 병소를 가진 다발성 뇌해면기형으로, 영상학적으로는 가 족성 제4형으로 여겨진다.

\section{REFERENCES}

1. Mespreuve M, Vanhoenacker F, Lemmerling M. Familial multiple cavernous malformation syndrome: MR features in this uncommon but silent threat. J Belg Soc Radiol 2016;100:51.

2. de Souza JM, Domingues RC, Cruz LC Jr, Domingues FS, Iasbeck T, Gasparetto EL. Susceptibility-weighted imaging for the evaluation of patients with familial cerebral cavernous malformations: a comparison with t2-weighted fast spin-echo and gradient-echo sequences. AJNR Am J Neuroradiol 2008;29:154-158.

Received December 21, 2018 Revised April 16, 2019

Accepted April 16, 2019

Address for comrespondence: Bong-Goo Yoo, MD

Department of Neurology, Kosin University Gospel Hospital, 262

Gamcheon-ro, Seo-gu, Busan 49267, Korea

Tel: +82-51-990-6461 Fax: +82-51-990-3077

E-mail: ybg99@naver.com 

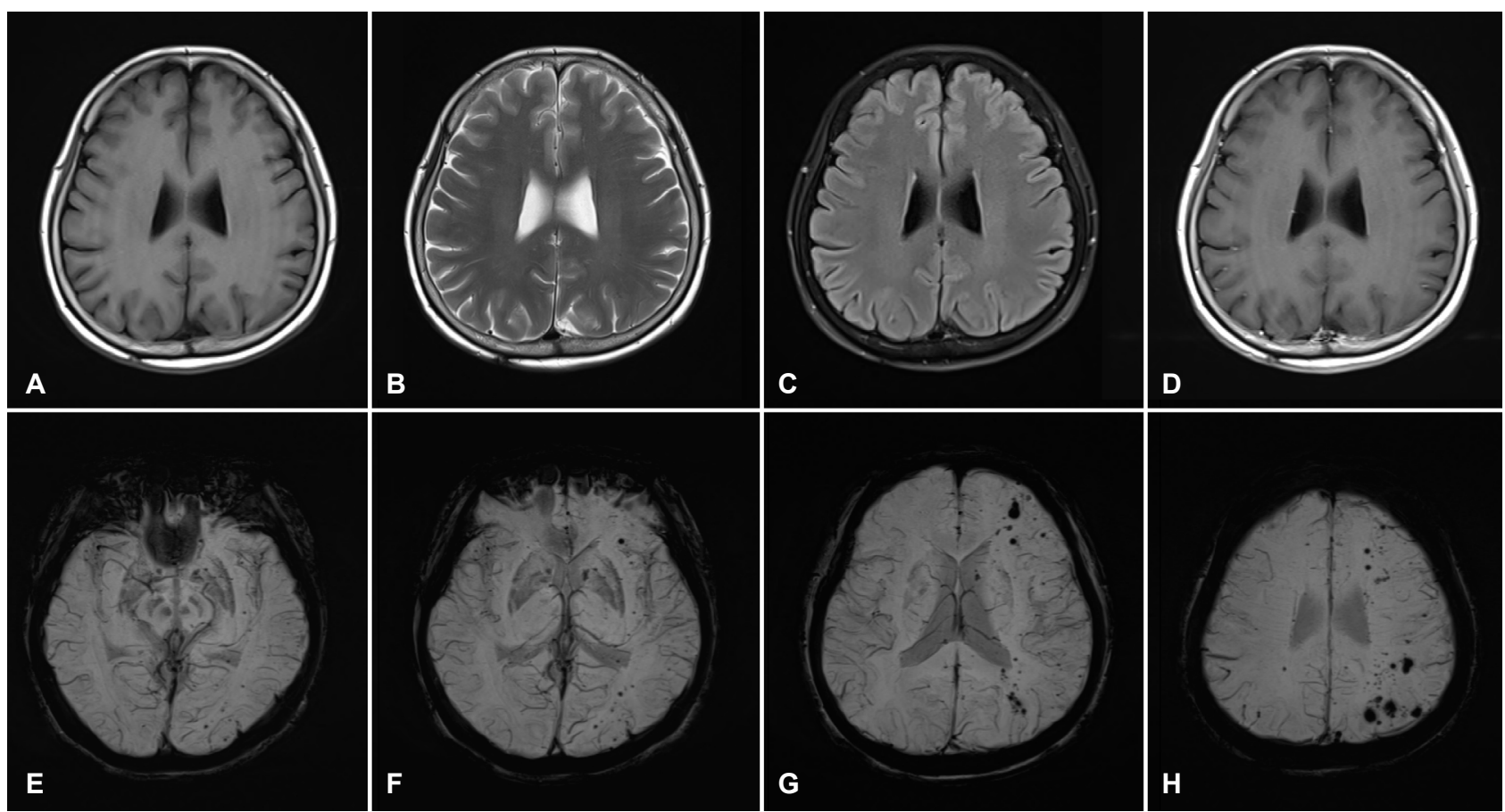

Figure. Brain magnetic resonance imaging of the patient. Axial T1-weighted (A), T2-weighted (B), fluid-attenuated inversion recovery (C), and enhanced T1-weighted (D) images show no significant abnormality. Susceptibility-weighted images (E-H) demonstrate numerous hypointense lesions with variable sizes distributed over the cerebral hemispheres. 